Article

\title{
Transpacific Cyberpunk: Transgeneric Interactions between Prose, Cinema, and Manga
}

\author{
Takayuki Tatsumi \\ Department of English, Keio University, Tokyo 108-8345, Japan; CXQ04644@nifty.com
}

Received: 4 December 2017; Accepted: 6 February 2018; Published: 2 March 2018

\begin{abstract}
This paper attempts to meditate upon the transpacific imagination of cyberpunk by reconstructing its literary and cultural heritage. Since the publication of William Gibson's multiple award winning first novel, Neuromancer (1984), the concept of cyberpunk has been globally popularized and disseminated not only in the field of literature but also in culture. However, we should not forget that cyberpunk is derived not only from the cutting edge of technology but also from "Lo Tek" sensibility cultivated in the Gibsonian picturesque ruins or dark cities such as a major extraterritorial zone in Hong Kong "Kowloon Walled City" nicknamed as "a den of iniquity", "The Casba of the East", and "a hotbed of crime", which was destroyed in 1993, but whose images captured by Ryuji Miyamoto inspired Gibson to come up with the spectacle of the destroyed San Francisco Bay Bridge to be stormed by ex-hippies and former homeless. From this perspective, this chapter focuses on the works ranging from Katsuhiro Otomo's directed anime Akira (1988), Gibson's Bridge Trilogy (Virtual Light (1993), Idoru (1996), and All Tomorrow's Parties (1998)) in the 1990s through Project Itoh's post-cyberpunk masterpiece Genocidal Organ (2007).
\end{abstract}

Keywords: cyberpunk; Lo Tek; outlaw technologist; extraterritorial; Kowloon Walled City; Hyperart Thomasson; virtual idol; post-apocalyptic narrative; nuclear politics

\section{Introduction: Akira, or Tokyo Olympic Games from 1964 to 2020}

The ongoing project of the Tokyo Olympic Games 2020 cannot help but remind me not simply of the Tokyo Olympic Games of 1964 I attended as an elementary school kid, but also of Otomo Katsuhiro's six volume cyberpunk manga Akira (Otomo 1982-1993) and its anime version, Akira (Otomo 1988), the 2019 setting of which had already supposed that the post-apocalyptic megalopolis Neo Tokyo would host the Tokyo Olympic in 2020. A reconsideration of this proto-cyberpunk narrative from 21st century's perspective will give us a wonderful key to comprehending the transpacific, extraterritorial, and post-apocalyptic elements peculiar to cyberpunk as such.

The story of Akira unfolds in downtown Neo Tokyo where the police keep fighting with the Pynchonesque counterforce, with special emphasis upon a couple of teams. On one hand, a team of extraordinary kids headed by Akira whose mental ability was so bio-technologically enhanced as to exhibit supernatural power comparable to nuclear energy. On the other hand, another team of punks formerly championed by Shima Tetsuo, who somehow happened to gain the same supernatural competence by taking a capsule containing a super-potent mind-altering substance, and whose prosthetic and cyborgian body gets metamorphosed into the man-machine interface of Neo Tokyo as such. Without a representation of cyberspace, the impact of Akira undoubtedly coincided with the rise of hardcore cyberpunks such as William Gibson and Bruce Sterling in early 1980s North America, who featured a brand-new anti-hero computer hacker as outlaw technologist very active in post-apocalyptic ruins and in the cyberspace matrix. Take an example of the "Lo Tek" spirit of a countercultural tribe Gibson created in one of his first cyberpunk tales, "Johnny Mnemonic" (1981), featuring a cyborg feminist Molly Millions, who would be the heroine of Neuromancer (1984). 
Here, Lo Teks make use of whatever is at hand on the street in order to outwit giant multinational corporations, just like computer hackers or cyberspace cowboys, that is, the emergent tribe of postmodern luddites (See Thomas Pynchon (1984), "Is It O.K. to be a Luddite?"). And you will quickly note the vision of Lo Tek to be shared by the punk kids Otomo describes in Akira and the human weapons distinguished director Shinya Tsukamoto represents in his Tetsuo trilogy (1989-2010), one of the major inheritors of the Japanese Apache created by Komatsu Sakyo, a founding father of Japanese science fiction, in his first novel Nippon Apacchi-zoku (The Japanese Apache (1964)) as I detailed in Full Metal Apache (Takayuki 2006). A further descendant of cyberpunk could well be easily noticed in director Neil Blomkamp's South African post-cyberpunk film, District 9 (2009), in which the natives of Johannesburg and the miserable aliens lost in space turn out to have the Lo Tek spirit in common; the former attempts to make use of aliens' high-tech weapons somehow, whereas the latter joins forces with human friends to find a way to return home.

However, what matters here is not that another Tokyo Olympic Games to come in the new century made me nostalgic for the cyberpunkish 1980s, but that the author of Akira born in 1954, only one year older than me, was also stimulated by the cultural incentive of the High Growth Period in the early 1960s, when our Tokyo was busy renovating itself in view of the huge international event. Then, how could we reconfigure the landscape of early 1960s Tokyo? In order to capture the image quickly, I would further expand the primal scene mentioned in the "acknowledgments" section of Full Metal Apache. As a child in downtown Tokyo in the mid-1950s and 1960s, I was shocked by the destruction and reconstruction of the Institute for Nature Study in Meguro, a unique botanical garden on Shirokane plateau which sat just in front of my house at the border between Meguro ward and Shibuya ward, and right in the path of construction for the Tokyo Metropolitan Expressway. This primal scene starts with the beautiful garden that had been my favorite playground, and the ugly construction machinery that split the very garden and deformed its whole landscape. However, I very soon found myself enjoying the in-between atmosphere of the construction, discovering a new playground in the chaotic and chimeric fusion of the natural forest with the high-tech expressway. Thus, I and my fellow kids started riding bicycles on the very construction site of the expressway, just like Kaneda, Tetsuo, and other punk kids of the speed tribes overdriving bikes in Neo Tokyo, near ground zero of the Third World War that took place in 1997. What is more, I was to discover later that the Institute for Nature Study had always already been more cultural than natural, not only in the way its "educational garden" reproduced plant communities from earlier days but also in the way it used to be an explosives warehouse back in Meiji Period (1868-1911) and a center closely related with Unit 731, a Japanese military unit notorious for testing on humans and animals illegally and developing new biological weapons during the Second Sino-Japanese War (1937-1945) of World War II, which cannot help but recall the way the human experimentations resulted in post-apocalypse in Akira. This is the reason why Shirokane tunnel constructed right under the expressway, splitting the formerly beautiful botanical garden, is rumored to have been haunted by a number of ghosts of the victims of Unit 731; quite a few passers-by have witnessed them. It is this primal scene that paved the way for my post-Ballardian, Gibsonian, and Harawayan sensibility, which I was to share with Shinya Tsukamoto, the distinguished cyberpunk director of the Tetsuo series, who also grew up in the Shibuya ward of the 1960s.

This primal scene narrates not simply the history of the High Growth Period but also the genesis of technological landscape as another nature. It is true that I was once depressed with the destruction of beautiful nature. However, once the Tokyo Metropolitan Expressway started to be under construction for the special convenience of international visitors for the 1964 Tokyo Olympics, we immediately got used to the new atmosphere, enjoying the border between the ruins and the construction site being made ambiguous. Yesterday's junkyard was miraculously metamorphosed into another nature. Without this fantastic memory, I could not have accepted cyberpunk in the early 1980s. Then, what will happen with the 2020 Tokyo Olympics? The Tokyo Metropolitan Government decided to move the famed Tsukiji fish market by the Tokyo Bay to a huge reclaimed area in Toyosu, infamous for soil 
contamination, in a plan to utilize the vacant space of Tsukiji as a logistics site for the Olympics to come. What is more, Tokyo Big Sight, an enormous international exhibition venue very well-known not simply for high-tech industries but also for Comiket (Comic Market), where a number of international fans (otaku) of science fictional subculture have long enjoyed selecting and purchasing many fanzines every August and December, will be exclusively used as the International Broadcasting Center and Main Press Center for the 2020 Tokyo Olympics. This bad news led many industries and Comiket participants to voice their discontent. It is ironic that the famed monuments of technological landscape naturalized after the 1964 Tokyo Olympics are supposed to be reorganized for the 2020 Tokyo Olympics, which will make a subcultural tribe another displaced people, or another Lo Tek, if only for the year. Yes, for me the essence of cyberpunk lies in not so much cyberspace as a junkyard, where punkish Lo Teks inhabit a transnational/deterritorialized zone and keep re-appropriating street technology with an aim of overturning the dominant culture. Without the image of the junkyard inhabited by Lo Teks, Gibson could not have conceived the vision of cyberspace, which is neither outerspace nor innerspace, but which enables cyberspace cowboys to master digital alchemy.

In order to celebrate the 30th anniversary of the anime version of Akira, I would like to speculate upon the extraterritorial significance of post-apocalyptic ruins in cyberpunk, especially focusing upon the works ranging from William Gibson's Bridge Trilogy (1993-1998) in the 1990s through to Project Itoh's post-cyberpunk masterpiece, Genocidal Organ (Murase 2017; Project Itoh 2012).

\section{Towards the Extraterritorial Poetics of Cyberpunk Literature}

William Gibson's 1980s Cyberspace Trilogy (Neuromancer (1984), Count Zero (1986) and Mona Lisa Overdrive (1988)) is followed by his 1990s Bridge Trilogy (Virtual Light (1993), Idoru (1996) and All Tomorrow's Parties (Gibson 1999)). The Bridge Trilogy starts with the near future San Francisco Earthquake nicknamed "the Little Grande" featuring Dr. Shinya Yamazaki, a sociologist from Osaka University who spends years in the homeless' unlawfully occupied space of San Francisco Bay Bridge (Virtual Light). Then, it transfers its emphasis from California to Tokyo, this time exploring the possibility of a nanotech marriage between a virtual idol, Rei Toei, and a male rock'n'roller, Lo Rez, within the reconstructed extraterritorial zone of Kowloon Walled City in cyberspace and by the Tokyo Bay (Idoru). Finally, the whole trilogy closes with a dramatic destruction of San Francisco Bay Bridge and the multiplication of the virtual idol through a nano-fax machine (All Tomorrow's Parties).

Why do I want to reconsider the significance of the trilogy, although I had already examined the first two novels in my book Full Metal Apache (Takayuki 2006)? The reason is very simple. The author's speculation in the Bridge Trilogy reveals his persistent obsession with the extraterritorial, which I neglected to explore in my previous discussion. Haunted by the nightmares of his own father as closely involved with Manhattan Project and the Vietnam War, Gibson discovered a way to evade the draft and expatriate himself from South Carolina to Toronto, Canada. Just the way William Faulkner defined himself as a product of the vanquished nation, that is, the American South after the Civil War, Gibson himself did not want to experience the second defeat of his nation through the Vietnam War, ending up with the original idea of cyberspace as a brand-new extraterritorial residence. As Bret Cox sharply pointed out, Gibson is a post-Faulknerian Southerner. Born in 1948 in Conway, South Carolina, he spent nearly 20 years in Southern states such as Virginia and Arizona. It is in 1968 that he moved to Toronto. Since then, except for a year's jaunt in Europe in the early 1970s, Gibson remained in Canada. In an interview conducted in 1993, Gibson confessed: "I'm still a guy from Virginia ... I'll never really be Canadian" (quoted in Brett Cox (2007), "Fragments of a Hologram Rose for Emily: William Gibson, Southern Writer"). Being aware of himself as a Southerner, Gibson never returned to the American South for nearly half a century, familiarizing himself with the multicultural atmosphere of Vancouver where he graduated from the Department of English at the University of British Columbia in 1977. At this point, we should not forget that he took a science fiction class taught by Susan Wood, which induced him to write his first short fiction "Fragments of a Hologram Rose". What is more, without spending years in Vancouver, a multicultural city which so vividly conjures up the image of Hong 
Kong as to be nicknamed "HongKongver", he could not have churned out the dark romantic image of Chiba City of Neuromancer. Yes, that phantasmagoric night town of Chiba City could not have been conceived without a transpacific negotiation between Vancouver and Hong Kong, if not a Japanese city itself. It is this complexity of deracinated identity that played the role of incubator for a brand-new world elsewhere, that is, cyberspace.

Before discussing the formation of expatriate sensibility, it is useful to reconsider the extraterritorial as defined by George Steiner in his book originally published in 1971. Although the extraterritorial has long been founded on the legal theory that certain persons and things, while within the territory of a foreign sovereign remained outside the reach of local judicial process, Steiner primarily redefines this adjective as someone so displaced (out of place or exiled) for various reasons as to command languages other than one's mother tongue. Thus, he renounces the myth of Romantic essentialism and gives an insight into the literary potentiality of radically displaced and virtually polylinguistic writers such as: Franz Kafka, Vladimir Nabokov, Jorges Louis Borges, Samuel Beckett, Ernest Hemingway, and others. Steiner concludes the first essay in the book as follows: "It seems proper that those who create art in a civilization of quasi-barbarism which has made so many homeless, which has torn up tongues and peoples by the root, should themselves be poets unhoused and wanderers across language" ((Steiner 1976), Extraterritorial: Papers on Literature and the Language Revolution (1971; New York: Atheneum, 1976) 11). Moreover, the author's reconfiguration of extraterritorial transcends the boundary of politics and linguistics so easily as to explore the frontiers of interdisciplinary field by incorporating the "mental energies and speculative forms of the sciences" into "educated literacy, into the normal life of the imagination" (Steiner xi). A rereading of Steiner today will convince us that today's list of extraterritorial writers never fails to ignore the name of William Gibson, whose displaced identity inspired him to come up with the brand-new language of cyberpunk, capable of expanding the interdisciplinary and extraterritorial zone between science and literature.

Therefore, what Gibson has consistently described in his novels is not so much the future of our civilization as the present of today's displaced people desperately seeking their own world elsewhere, another name for the extraterritorial zone as represented by cyberspace, the occupied bridge, and Kowloon Walled City both virtual and substantial.

Chronologically speaking, the moment Gibson shifts emphasis from cyberspace to junkyard was noticed when he paid the first visit to Japan in the winter of 1988. Celebrating the completion of the Cyberspace Trilogy, we had a welcome party for him at an ethnic restaurant called Sunda located just in front of NHK (Japan Broadcasting Corporation) in Jinnan, Shibuya ward, Tokyo, along with a bunch of writers, critics, editors, and film directors. Therefore, it was very natural for me to introduce him to one of our distinguished cyberpunkish filmmakers, Ishii Sogo, who had been already well-known for a pre-cyberpunk movie, Burst City (1982). Gibson and Ishii started talking about the possibility of their future collaboration. It is regrettable that they could not complete this project. And yet, the conversation with Ishii inspired Gibson to grasp the essence of his 1990s Bridge Trilogy. Let us take a look at his acknowledgments to Idoru:

Sogho Ishii, the Japanese director, introduced me to Kowloon Walled City via the photographs of Ryuji Miyamoto. It was Ishii-san's idea that we should make a science fiction movie there. We never did, but the Walled City continued to haunt me, though I knew no more about it than I could gather from Miyamoto's stunning images, which eventually provided most of the texture for the Bridge in my novel Virtual Light. ("Thanks" Idoru (New York: Putnam, 1996))

If you start reading the Bridge Trilogy chronologically, you will be deeply impressed with the way San Francisco Bay Bridge occupied by the homeless is replaced by another Kowloon Walled City reconstructed in cyberspace and Tokyo Bay. However, it is Ryuji Miyamoto's photographic collection of Kowloon Walled City, the most illegally built construction in world history, that first captured Gibson's cyberpunk/Lo Tek imagination in the winter of 1988, leading him to write a short story "Skinner's Room" in 1989, based upon the image of the destroyed Bay Bridge as a collaboration with talented 
architects Ming Fung and Craig Hodgetts for Paolo Polledri's exhibition, "Visionary San Francisco", held in 1989 at San Francisco Museum of Modern Art. It is the Asian Gothic image of Kowloon Walled City as another extraterritorial zone that had first inspired Gibson to represent the near future San Francisco Bay Bridge occupied by the unhoused, not vice versa. Herein lies the extraterritorial seeds of transpacific cyberpunk.

\section{From San Francisco Bay Bridge to Kowloon Walled City}

To tell the truth, even the junk art-like bridge-scape of Virtual Light had already been familiar to Postmodern Japanese aesthetics. Indeed, this novel beautifully envisions the near future post-earthquake San Francisco Bay Bridge in 2005, around when California itself has split into two states- "SoCal" and "NoCal". With the Bay Bridge linking San Francisco and Oakland closed, this catastrophe induced ex-hippies and former homeless to storm the very bridge space and build themselves a new self-governing community therein, and re-design the whole bridge, whose Neo-Dadaistic arcology is to be named "Thomasson" by Yamazaki, the Japanese sociologist from Osaka University conducting research on the formation of the bridge culture. While the archetypal short story "Skinner's Room" does not allude to "Thomasson", the novel version brilliantly reflects this Neo-Dadaistic aesthetics in representing the occupied bridge:

Its steel bones, its stranded tendons, were lost within an accretion of dreams: tattoo parlors, gaming arcades, dimly lit stalls stacked with decaying magazines, sellers of fireworks, of cut bait, betting shops, sushi bars, unlicensed pawnbrokers, herbalists, barbers, bars. Dreams of commerce, their locations generally corresponding with the decks that had once carried vehicular traffic; while above them, rising to the very peaks of the cable towers, lifted the intricately suspended barrio, with its unnumbered population and its zones of more private fantasy ... In all the world, surely, there was no more magnificent a Thomasson. (William Gibson (1993), Virtual Light (New York: Bantam), chp. 6, “The Bridge”, pp. 62-63)

What is Thomasson? The author explains its etymology in the novel as follows:

Thomasson was an American baseball player, very handsome, very powerful. He went to the Yomiuri Giants in 1982, for a large sum of money. Then it was discovered that he could not hit the ball. The writer Gempei Akasegawa appropriated his name to describe certain useless and inexplicable monuments, pointless yet curiously artlike features of the urban landscape. But the term has subsequently taken on other shades of meaning. If you wish, I can access and translate today's definitions in our Gendai Yogo no Kisochishiki, that is, The Basic Knowledge of Modern Times. (Virtual Light, Chapter 6, "The Bridge", pp. 64-65)

However, the novel gives us no further analysis of this hyperart, illustrating the point with no examples Genpei Akasegawa enumerates in downtown Tokyo. In my former article on the novel originally published in 1995, I only redefined this hyperart as closely intertwined with Marcel Duchamp and Joseph Cornell whose Dadaist works Gibson had long been fascinated with not only in Neuromancer but also in Count Zero. At that point, I simply emphasized the way Akasegawa the Neo-Dadaist radically "Japanized" Duchamp as the near-precursor of Thomasson, who "could not attain Thomassonian perfection unluckily", but whose sense of "non-art" brilliantly "corresponded with the Japanese heritage of tea ceremony represeted by Sen-no-Rikyu", in which the very natural world has persistently been considered full of "readymade" objects (Genpei Akasegawa, Geijutsu Genron (The Principles of Art), pp. 249-59). Therefore, when Virtual Light was first published in 1993, I attempted to relate the aesthetics of Neo-Dadaist art with the ecology of post-countercultural tree house Gibson must have been familiar with. With the Bridge Trilogy completed in 1999, however, I feel it indispensable to link this hyperart with Kowloon Walled City, high-technologically replicated.

In retrospect, the archeology of ruins tells us, it is the Dissolution of the Monasteries ordered by Henry VIII between 1536 and 1541 that made quite a few Catholic abbeys the typical ruins, which 
only attracted opportunistic businessmen and melancholy antiquaries. However, in the course of three centuries, straight forward greed was followed by ignorance and indifference, and curiosity led to veneration (Christopher Woodward (2001), In Ruins, p. 109). Without Henry VIII's transformation of the abbeys into ruins, English literary history could not have developed the imagination of Gothic Romance. Likewise, without postwar apocalyptic tragedies, whether natural or political, postmodern literature could not have cultivated the imagination of cyberpunk junkyard as another extraterritorial playground.

This perspective allows me to illustrate Thomasson with mysterious and indefinable objects in the Tokyo cityscape. Akasegawa once defined a Thomasson as any kind of "useless and defunct object attached to someone's property and aesthetically maintained". The kind of Thomassons he discovered included: the doorknob in a wall without a door, that driveway leading into an unbroken fence, that strange concrete, thing sprouting out of your sidewalk with no discernible purpose (John Metcalfe (2012), "Useless and Defunct City Objects Should be Called ... 'Thomassons'”, (http:/ / www.citylab.com/design/2012/05/useless-and-defunct-city-objects-are-named-thomas sons/2075). The most famous one among them is nicknamed "Yotsuya no Junsui Kaidan" (Pure staircase of Yotsuya) or simply "Yotsuya Kaidan", a flight of stairs leading into a blank wall without a door, with the handrail still being maintained. You could well be amused by this nomenclature, for "Yotsuya Kaidan" derives from a pun as the strange staircase (kaidan) located in Yotsuya, Shinjuku ward, and a ghost story (kwaidan) originated in the same town and well known as a Kabuki play performed time and again. Our contemporary high-tech city, especially in the wake of quite a few apocalypses-such as World War II, huge earthquakes, and the burst of the bubble economy-became indistinguishable from artistic ruins filled with numerous Thomassons, that is, mysterious objects which seem to be useful at first glance, but which turn out to be not simply dysfunctional but also hyperartistic. What creates Thomassons is not the genius of romantic artists in the attic, but the gaze of flaneurs strolling aimlessly through the streets. Therefore, in 1986 Akasegawa and his collegues such as Fujimori Terunobu, Matsuda Tetsuo, Minami Shimbo, and Hayashi Joji formed a society for observing objects on the streets. The strange objects compiled into their photo album included: a vegetable wiper, a vegetable television, an ornithic television, and others.

What attracts me most now is one of the Thomassons entitled "Kowloon Walled City for Chickens" discovered and photographed by Hayashi Joji in 1986. This photo captures the image of a nearly four-storied huge but chaotic chicken house with a couple of big flowerpots on top. Certainly, before writing Virtual Light in 1993, Gibson confessed to having seen Miyamoto Ryuji's photographic collection of Kowloon Walled City in 1988. And yet, it is indeterminable if Gibson also noticed one of many Thomassons entitled "Kowloon Walled City for Chickens" when he picked up the concept of the hyperart as perfect metaphor for bridge culture. What matters here is that already in the mid-1980s, even the founding fathers of Neo-Dadaism somehow gave an insight into an analogy between the Hyperart: Thomasson and Kowloon Walled City (See Genpei Akasegawa (2009), Cho-Geijutsu Tomason (HyperArt: Thomasson)).

Then, how important is Kowloon Walled City in Hong Kong for postmodern culture and literature? As summed up above, Gibson's fifth novel called Idoru (Gibson 1996), the companion piece of his fourth novel Virtual Light (Gibson 1993), features a romance between the rock'n'roller, Lo Rez, and the Asian AI heroine, Rei Toei, in 2006, almost one year after the post-earthquake events on the San Francisco Bay Bridge narrated in Virtual Light. Around this period, nanotech engineering enabled the post-earthquake Tokyo to be reconstructed quickly. Elaborate virtual spaces have been constructed as well, even replicating the whole "bad taste" structure of the Kowloon Walled City (Hak Nam), a place of interest in Hong Kong destroyed in 1993. Note that it is not only Gibson but also numerous postmodern artists who lamented the destruction of the greatest place of interest in Hong Kong. Thus, the 1996 publication of this novel, Idoru, beautifully coincides with the creation of the latest Japanese "post-cyberpunk" computer game, "Kowloon's Gate", directed by Nakaji Kimura (1997) and marketed in 1997 by Sony Music Entertainment, featuring a distinguished feng shui master who is to 
restore the equilibrium between yin and yang abruptly jeopardized in the very year of 1997 by the intrusion of the unreal Kowloon Walled City (within the yin area) into the real world (within the yang area). Weirdly nightmarish as it seems, the extraterritoriality of Kowloon Walled City appealed to a variety of postmodern artists and writers.

Historically speaking, the origin of Kowloon Walled City, a weird extraterritorial space of 2.7 hectares located a few-hundred meters to the northwest of Hong Kong's Kai Tak International Airport, could well be located in the Sung Dynasty of the fifth century. Nonetheless, it is after the outbreak of the Opium War in 1839 that this site came to gain more military importance. As Kenichi Ohashi spells out, with the defeat of the Ch'ing forces in 1842 the Treaty of Nanking was signed and Britain took possession of the Island of Hong Kong-prompting the Ch'ing to build an actual walled fortress in Kowloon by 1847. Even after the Treaty of Peking in 1860, which enabled Britain to obtain the Kowloon Peninsula south of Boundary Street, the Walled City of Kowloon exceptionally remained under $\mathrm{Ch}^{\prime}$ ing jurisdiction. Therefore, this site had to retain the double status of extraterritoriality. Although Hong Kong became British legally, only this site kept being controlled by the Chinese government. Nonetheless, what with the Japanese occupation of the site in 1941 and what with the popular resistance ending up with the burning of the British Consulate in Kanton, disagreements over the status of the Kowloon Walled City between the Chinese and British governments dramatically increased. Thus, the city itself gradually became a kind of diplomatic black hole, existing in limbo between two countries, inviting a number of refugees and displaced people to inhabit the very extraterritorial site; they all wanted to avoid taxation or legal interference from the colonial government. What is more, this site was convenient for the Chinese Triad societies, which popularized the idea that it was Chinese territory and therefore was not subject to Hong Kong law to promote their illegal dealings such as gambling, drug trafficking, and prostitution. In this way, Kowloon Walled City came to be nicknamed as "a den of iniquity", "The Casba of the East", and "a hotbed of crime" (Ohashi, "The History of the Kowloon Walled City", tr. Keith Vincent in Ryuji Miyamoto (1997), Kowloon Walled City (Tokyo: Heibonsha Publishers, 1997), pp. 152-55).

With this history in mind, you will fully enjoy Gibson's representation of Kowloon Walled City replicated within cyberspace. With the help of an Otaku boy Masahiko usually spending hours in the site, the heroine Chia McKenzie, a 14-year-old girl from Seattle and a big fan of Lo Rez, vividly witnesses the gigantic structure:

Chia reached up and pulled her own glasses down, over her eyes.

"What do I ..."

Something at the core of things moved simultaneously in mutually impossible directions. It wasn't even like porting. Software conflict? Faint impression of light through a fluttering of rags.

And then the thing before her: building or biomass or cliff face looming there, in countless unplanned strata, nothing about it even or regular. Accreted patchwork of shallow random balconies, thousands of small windows throwing back blank silver rectangles of fog. Stretching either way to the periphery of vision, and on the high, uneven crest of that ragged facade, a black for of twisted pipe, antennas sagging under vine growth of cable. And past this scribbled border a sky where colors crawled like gasoline on water.

"Hak Nam," he said, beside her.

"What is it?"

"'City of darkness', Between the walls of the world." ...

"The Walled City is a concept of scale. Very important. Scale is place, yes? Thirty-three thousand people inhabited original. Two-point-seven hectares. As many as fourteen stories." (William Gibson, Idoru (New York: Putnam, 1996) Chapter 26, “Hak Nam,” pp. 181-82) 
The novel reaches the greatest climax when the cutting-edge nanotechnology succeeded in replicating the same City by the Tokyo Bay almost miraculously:

The Walled City is growing. Being grown. From the fabric of the beach, wrack and wreckage of the world before things changed. ( ... ) A thing of random human accretion, monstrous and superb, it is being reconstituted here, retranslated from its later incarnation as a realm of consensual fantasy. (Gibson, Idoru, chp. 46, "Fables of the Reconstruction", p. 289)

Of course, Lo Rez's desire to get married to Rei Toei as AI sounds quite childish in the first place, for Lo Rez is human, Rei artificial. However, as is the case with Zona, Chia's close friend in Mexico, who proves to be half-virtual, it is not unusual that the most intimate friend of yours might be only hovering on the boundary between the human and the artificial. This principle is also applicable of Kowloon Walled City. Now that Kowloon Walled City, despite the residents' persistent resistance, was torn down in 1993, we are able to experience it only cybernetically on the border between reality and virtual reality. The reason why the site is still alive in people's memory is very simple. As Miyamoto Ryuji himself redefined it in "A Vanished City", the preface to his photographic collection: "The Kowloon Walled City was a massive crystallization of the communal unconscious of the Chinese; a miraculous, uncommonly transcendent phenomenon of human ingenuity which just happened to rise up before our eyes" (pp. 6-7). Thus, in my guest-edited issue of the Asahi Weekly Encyclopedia featuring science fiction and slipstream literature (2000), I once stated that "if I'm permitted to visually represent the zeitgeist of boundary transgression, I feel no hesitation to select the Kowloon Walled City as its objective correlative ... Although Chinese government destroyed it in 1993, this City still keeps inspiring writers and artists to produce novels and video games with the very site as the main setting. While it used to hover over the political boundary between Britain and China, this huge walled city now deconstructs and reinvents itself the very epistemological boundary between reality and virtual reality" (The Asahi Weekly Encyclopedia, No. 48 (Tokyo: Asahi Shimbun Publishers, Takayuki 2000)). With the rise of Brexit that set up a border between the EU and UK and the Trump presidency that promises to complete the US-Mexico border wall, both of which took place in the same year of 2017 and which requires displaced people to leave their ultra-conservative nations and dream of another extraterritorial zone in the second decade of the 21st century, the late Kowloon Walled City is gaining more and more significance.

\section{Conclusions: Ghosts in the City, or Genocidal Organ}

The Kowloon Walled City vanished from the earth in 1993. However, as the legendary game Kowloon's Gate still keeps haunting our mind, we are still likely to envision a number of ghosts and monsters very active in the imaginary City. Yes, it is the ghost of the very city that has long obsessed us, for cyberpunk has persistently questioned the boundaries between the organic and the mechanic, the living and the dead, civilization and junkyard.

Now please recall the introduction of the paper, where I started by talking about the post-apocalyptic junkyard of 2019 Neo Tokyo in Akira overwrapping with the construction site of the Tokyo Metropolitan Expressway fusing seamlessly with the destruction site of the beautiful botanical garden of the Institute for Nature Study in 1963 Tokyo. As Akira narrates the aftermath of human experimentation that had brought about the nightmare of total apocalypse, the real Institute for Nature Study secretly contains the military tragedy of human/animal experimentation that was to produce quite a few ghost stories closely related with the tunnel under the very expressway. Just like The Ghost in the Shell (1995) and its sequel Innocence (2004), we are not free from the preternatural within the techno-scape of our megalopolis. With this context in mind, it was amusing to see a fantastic cafe restaurant "Giger Bar" constructed in the late 1980s near the entrance of Shirokane tunnel right under said expressway, receiving popularity until the mid-1990s when troubles with yakuza forced the manager to close the restaurant. However, note that as the name suggested, its organic and 
biomechanical atmosphere was inspired by distinguished Zurich-based artist H. R. Giger, well-known for the cover jacket of prog rock band Emerson, Lake, and Palmer's Brain Salad Surgery (1973) and also for the art direction of Ridley Scott's film, Alien (1979). Famous as he is for the hardcore cyberpunk Blade Runner (1982), Scott should be further appreciated as the prophet of alternative cyberpunk as is outlined in Alien (1979), one of whose sequels (Alien 3) was to be written by William Gibson himself in vain. Anyway, to me it does not seem coincidental that the heyday of the bubble economy around 1990 saw the cyberpunk taste of Giger Bar Tokyo located just in the neighborhood of Shirokane Tunnel haunted by the ghosts of pre-cyberpunkish biomechanical experiments.

Let me close the chapter with a note on the latest fruit of transpacific cyberpunk, Murase Shukou's directed anime, Genocidal Organ (Murase 2017), a faithful adaptation of self-claimed cyberpunk writer Project Itoh's masterpiece, finalist for the seventh Komatsu Sakyo Award in 2006 and originally published in 2007. This title simply presupposes the existence of genocidal organ deeply embedded within human linguistic ability, which will boot up through a secret code discovered and mastered by an enigmatic linguist, John Paul. It is undoubtedly the march of folly from the Rwandan genocide in 1994 through the September 11 Terrorist Attacks and the Iraq War in the early 2000s that invited the author Project Itoh to create this mysterious character John Paul, a former PR man who grasped the secrecy of the genocidal organ within the human organism. Just the way Tyron Slothrop's making love never fails to be followed by the assault of a V2 rocket in Thomas Pynchon's pre-cyberpunk mega-novel Gravity's Rainbow (1973), John Paul travels "from war zone to war zone" (p. 57), as if he is the prime mover of war itself. He keeps causing wars by secretly driving the genocidal organ and producing a number of ruins, the homeland of extraterritorial and Lo Tek people including himself. Thus, desperately seeking John Paul, the protagonist/narrator Clavis Shepherd recognizes the fact: "This man who we'd tried and failed to kill on numerous occasions had somehow been a catalyst for genocide in locations throughout the world. For some reason, when this man went into a country, it plunged into chaos. For some reason, when this man went into a country, the blood of innocents would pour forth" (p. 78). The concept of the novel itself very naturally reminds us of what Hannah Arendt called the "banality of evil" in her Eichmann in Jerusalem (Arendt 1994), Project Itoh's originality lies not in his narrativization of Eichmann-like characters in war zones but in his speculation on an imaginary organ inherent deep within human linguistic competence that gets started through the speech act of the very spell John Paul discovered. Although the precise identity of the spell remains unknown throughout the novel, the mysterious stranger John Paul could well be reconceived as a kind of talented cyberspace cowboy who could very easily get access to the secret of human nature that could otherwise have been kept confidential. In this sense, Genocidal Organ also recalls the hardcore cyberpunk, Akira, which centers around the secret of the universe the enfant terrible Akira conceals within himself. Furthermore, we should not forget that while genocidal organ remains a secrecy for human beings, the rapid growth of the huge African industry of artificial flesh was made possible through harvesting from "genetically modified aquatic mammals such as dolphins and whales" (p. 259). On one hand, if we focus on the narrative of John Paul, it's readable as a hardcore Gibsonian Quest for the Holy Grail: while Gibson's characters desperately seek for treasure, Itoh's hero looks for death. On the other hand, if we take a careful look at artificial flesh employed not only for military operations but also for various reasons, the whole narrative begins to show the post-Gigerian aesthetics at the risk of today's eco-critical imperative.

However, what I would like to call your attention to most is the post-apocalyptic aspect of the novel/anime of Genocidal Organ. Although cyberpunk narratives have scarcely been discussed in the eschatological context, its genealogy from Blade Runner, the Cyberspace Trilogy/the Bridge Trilogy, Akira, down to Genocidal Organ all presupposes a kind of end of the world that had already taken place before the beginning of each story. If Gibson invented cyberspace as an extraterritorial zone exempt either from the draft or from nuclear politics his own father had been responsible for, it makes perfect sense to reconsider cyberpunk as another post-apocalyptic narrative. And we have to note that also in 
this respect Project Itoh gives a deep insight into the essence of war. In the wake of nuclear destruction of an Eastern European city:

The world changed the day the bomb exploded in Sarajevo. The era of Hiroshima was brought to a close once and for all. All around the world the military suddenly started waking up to the fact that their theoretical weapons of mutually assured destruction were maybe not so theoretical after all. Nuclear weapons were back on the table as an option. (p. 205)

Theoretically speaking, the end of the world should allow for no survivors. However, it is true that post-apocalyptic narratives cannot fail to describe the life of survivors without the sense of contradiction, as is seen in Komatsu Sakyo's Virus (1964) which depicts the way the world sees apocalypse twice, first caused by a mysterious pandemic and second by a total nuclear war. Note that while Komatsu, one of the founding fathers of modern Japanese science fiction, closed his post-apocalyptic narrative with an optimistic vision of humankind, Project Itoh, who Komatsu himself discovered and selected as finalist for the seventh Komatsu Sakyo award, concludes the novel by letting the narrator Clavis Shepard inherit the grammar of genocide from John Paul which he rammed home into the United States. "The deep structure of genocide has spread across the whole of America, quickly and easily, using English as its vector" (p. 297). Now we witness the birth of new Lo Tek in the 21st century, who is able not only to control but also to destroy the world through his mastery of the new grammar. A big fan of J. G. Ballard, a major speculative fictionist who published a number of dystopian stories, John Paul very possibly dreamed of a world in ruins. "Spaceship Mother Earth, a giant, unmanned satellite that silently orbited the sun. A world where aliens would land one day and find only the traces of civilization long destroyed, the empty husks of building after building whose inhabitants had long since disappeared" (p. 107). In the meantime, William Gibson, another big fan of Ballard, has also been obsessed with apocalyptic and posthumanist visions, which have tremendous impact upon the post-apocalyptic simulated reality, "the desert of the real", beautifully described in the Matrix trilogy (1999-2003) directed by the Wachowski Brothers. Although visual technology, as Akira Mizuta Lippit (2005) pointed out in Atomic Light (Shadow Optics), came to transfigure the impact of the atomic bombings of Hiroshima and Nagasaki into the tropes of invisibility or transparency, it is also true that from its inception cyberpunk literature has never been immune from the nightmare of nuclear apocalypse.

Thus, transpacific cyberpunks will continue narrating the world after the end of the world, refreshing the memory of Hiroshima and Nagasaki as the first nuclear war. This is the reason why our survivors will also keep seeking the extraterritorial zone, making the border between the ruins and the construction site ambiguous.

Acknowledgments: The earliest version of this paper was first delivered as a keynote lecture at the annual conference of Mechademia held at Minneapolis College of Arts and Design on 23 September 2017 (Saturday). The author expresses the deepest gratitude to Frenchy Lunning, the Editor-in-Chief of Mechademia.

Conflicts of Interest: The author declares no conflict of interest.

\section{References}

Akasegawa, Genpei. 2009. Cho-Geijutsu Tomason (Hyperart: Thomasson). Translated by Matthew Fargo. New York: Kaya Press.

Arendt, Hannah. 1994. Eichmann in Jerusalem: a Report on the Banality of Evil. New York: Penguin.

Cox, F. Brett. 2007. Fragments of a Hologram Rose for Emily: William Gibson, Southern Writer. In The Cultural Influences of William Gibson, the "Father" of Cyberpunk Science Fiction: Critical and Interpretive Essays. Edited by Yoke, Carl and Carol L. Robinson. Lewiston: Edwin Mellen.

Gibson, William. 1993. Virtual Light. New York: Bantam.

Gibson, William. 1996. Idoru. New York: Penguin.

Gibson, William. 1999. All Tomorrow's Parties. New York: Putnam. 
Kimura, Nakaji. 1997. Kowloon's Gate. Tokyo: Sony Music Entertainment.

Lippit, Akira Mizutat. 2005. Atomic Light (Shadow Optics). Minneapolis: U of Minnesota P.

Metcalfe, John. 2012. Useless and Defunct City Objects Should be Called ... 'Thomassons'. Available online: http:/ / www.citylab.com/design/2012/05/useless-and-defunct-city-objects-are-named-thomassons /2075/ (accessed on 4 December 2017).

Miyamoto, Ryuji. 1997. Kowloon Walled City. Translated by Keith Vincent. Tokyo: Heibonsha.

Murase, Shukou. 2017. Genocidal Organ. Tokyo: Toho.

Otomo, Katsuhiro. 1982-1993. Akira. 6 vols; Tokyo: Kodansha.

Otomo, Katsuhiro. 1988. Akira. Tokyo: Toho.

Project Itoh. 2012. Genocidal Organ. Translated by Edwin Hawkes. San Francisco: Haikasoru.

Pynchon, Thomas. 1984. Is It O.K. to be a Luddite? The New York Times Book Review 1: 40-41.

Steiner, George. 1976. Extraterritorial: Papers on Literature and the Language Revolution. New York: Atheneum.

Takayuki, Tatsumi, ed. 2000. The Asahi Weekly Encyclopedia No. 48. Tokyo: Asahi Shimbun Publishers.

Takayuki, Tatsumi. 2006. Full Metal Apache: Transactions between Cyberpunk Japan and Avant-Pop America. Durham: Duke UP.

Woodward, Christopher. 2001. In Ruins. New York: Pantheon.

(c) 2018 by the author. Licensee MDPI, Basel, Switzerland. This article is an open access article distributed under the terms and conditions of the Creative Commons Attribution (CC BY) license (http://creativecommons.org/licenses/by/4.0/). 